\title{
A STUDY TO EXPLORE LEARNING STYLE PREFERENCES OF PHARMACY STUDENTS WITH REGARD TO PHARMACEUTICAL CALCULATIONS
}

\author{
BAHTA WARA, JAN DALY, HANA MORRISSEY, PATRICK BALL \\ School of Pharmacy, Faculty of Science and Engineering, University of Wolverhampton, United Kingdom \\ Email: hana.morrissey@wlv.ac.uk
}

Received: 15 Apr 2019, Revised and Accepted: 13 Jun 2019

\begin{abstract}
Objective: Pharmaceutical calculations are an essential aspect of learning for pharmacy students in order to avoid drug dose errors and maintain patient safety in future practice. Learning styles influence how lecturers approach the teaching-learning process. So far no specific learning preference is believed to be most appropriate for the pharmacy curricular; however certain learning styles are favoured by students as they improve their understanding of course material, knowledge and performance.
\end{abstract}

Methods: 148Master of pharmacy participants from the second and third year were given a questionnaire to complete during a compulsory Individual Readiness Assurance Test session. Participants were restricted to just one option.

Results: Workshops with a tutor was the most selected (36\%) followed by $25 \%$ of participants favouring formative assessments, $28 \%$ selected workbooks alone, $37 \%$ for whole-class lecturers and videos option was the least selected. Reasons for the most and least preferred learning styles were highlighted and separated into advantages and disadvantages using themes. In the knowledge test; $92 \%$ of participants selected "unsure" or "didn't know" the answer, 29\% had a partially correct answer and 19\% selected incorrect answers.

The overall order of ranking arose in regards to the most beneficial learning style which enhances performance. The responses revealed a variety of advantages and disadvantages which were reflected between year groups and similar to views obtained from recent literature. Students reflected a lack of understanding on extemporaneous preparation (EPs) terms used in pharmaceutical compounding practices, thus the university should consider addressing the lack of awareness and consider the best teaching-learning style in doing so.

Conclusion: Overall the findings suggested that the sample students have similar views on the learning styles used to deliver pharmaceutical calculations on their academic performance to that expressed by the authors from recent published literature.

Keywords: Pharmaceutical calculations, Learning styles, University, Preference, Academic performance

(C) 2019 The Authors. Published by Innovare Academic Sciences Pvt Ltd. This is an open access article under the CC BY license (http://creativecommons.org/licenses/by/4.0/] DOI: http://dx.doi.org/10.22159/ijcpr.2019v11i4.34933

\section{INTRODUCTION}

The use of pharmaceutical calculations (PCs) in practice is fundamental to patient safety $[1,2]$. Pharmacists must calculate doses tailored for specific patients, avoiding both toxic and subtherapeutic doses for any route of administration [3].

The General Pharmaceutical Council (GPhC) requires pharmacy graduates to pass a registration examination in which one part is solely based on PCs. Candidates must achieve $70 \%$ to qualify [4]. Regular practice of various PCs throughout the course will build stable background at university [5].

In 2014, the University of Wolverhampton (UoW) altered their course structure. The new structure includes teaching the mathematical skills required, plus multiple opportunities within each academic year to practise, improve and evaluate PC skills [6].

A variety of learning styles and support materials are used by universities to improve teaching and academic performance [7]. To date, no specific delivery style has been identified as the most appropriate for the pharmacy curriculum ${ }^{8}$, but certain styles have been preferred as they appear to improve students' understanding of course material, overall knowledge and performance. This means students achieve more confidence in carrying out calculations, [9$11]$ to avoid drug dose errors and promote patient safety $[2,12]$.

One method of teaching PCs is via an e-learning, non-credit based module (topic tutorials, work booklets and self-assessments [13]. Students are enabled to progress at their own pace, in their own comfort zones. They gain direct feedback, increasing their understanding of the sub-topics [14]. However, students find some topics within the module less relevant to them or that tutorials to take up too much time and the degree of ease/difficulty is not uniform. Also, students who are less computer-literate are discouraged, [13]. Van [15] claims students attending traditional face to face lectures greatly improved in performance when compared to e-learning modules.

The standard lecture format at UoW covers a presentation, made available $24 \mathrm{~h}$ before a timetabled session [16]. Both lecturers and students reportedly enjoy this style of teaching; benefits include interaction with lecturers' face to face [17], team work and class discussions amongst students5. However, Fike [17] reported students' attendance declined around assessments due dates ( $80 \%$ or less), but no significant difference in grades was identified between students who attended lectures and those who did not. Preszler and Hoopes [10] claimed that students prefer attending more valuable smaller tutorials compared to weekly lectures.

Interactive workshops comprised of small groups of students' solving practice-scenario challenging questions. Their workshops were designed to improve students' skills to an appropriate level of understanding, application and competence [10]. According to Batchelor [5] more than 50\% of students learn better in workshops compared to lectures. Further, the use of team work within these sessions increased scores $>20 \%$ compared to individual marks [9]. Workshops appear able to improve students' understanding of course materials, making them confident in carrying out calculations [9].

A more recent concept being used to teach PCs is video recordings; a complete presentation is recorded by the lecturer and made available to students to download or simply watch online [16]. In this model, lecturers are able to track student engagement and students are able revisit concepts multiple times to understand 
course material, enhancing learning [16, 18]. Glaister [19] claimed computerised learning was effective at developing knowledge and Karyn [16] claimed higher exam grades were achieved when students used videos. However, students reported being stressed when applying concepts and solving question immediately following intensive video, reporting a perception that extra time was required [16]. Van [15] claimed that although this form of learning had some benefits, traditional didactic lectures were more effective in terms of student achievement.

Another learning style is the use of formative assessments [13, 20]. Students undertake these in a location of their choice, without the use of any materials. They cover a range of topics of varying difficulty $[13,21]$. These mini-tests were claimed to improve skills and performance [22] as they assess students' knowledge, retention and the ability to apply concepts $[3,20]$. After having completed the exercises, rapid, detailed feedback is received, allowing learning adjustments to be made and also the opportunity of repeated practice [23, 24]. Feedback delivered included solutions with detailed working, and an opportunity to seek one to one support [23, 24]. Gums [22] claimed higher test scores were noted due to this form of individualised feedback, whitensz and Frosch [21] demonstrated that students who take these regular quizzes and assessments experience less stress than they did in the past, when taking summative examinations.

Learning influences how lecturers approach the teaching-learning process [25]. The array of learning styles available have clear benefits and issues. Exposing students to the variety of styles available, provides the opportunity to exercise judgement on how they prefer to learn 5 and determine which learning style will promote application and competence [26].

The aim of this project was to highlight pharmacy students' preferences of learning styles with respect to PCs.

The three main objectives of this project are:

- To identify and analyse the views of pharmacy students on PC learning styles.

- To analyse the reasoning for their most and least preferred learning styles.

- To capture and determine the advantages and disadvantages of each learning style.

\section{MATERIALS AND METHODS}

\section{Methods}

Two cohorts from the MPharm students at the University of Wolverhampton, Wolverhampton, UK. Students were recruited from second and third year classes $(n=168)$. A self-administered questionnaire was selected as the most appropriate data collection tool. The study was approved by the School of Pharmacy Ethical Review Board. Open-ended and closed-ended questions were used in the questionnaire, to minimise the disadvantages of using one type of question alone. A ranking system was also used to rank preferences over the five currently used learning styles. This allowed participants to avoid selecting all learning styles as most or least preferred assigning a unique value to a learning style [43].

Table 1: Categorised questions used in the questionnaire

\begin{tabular}{ll}
\hline Types of questions & Open-ended \\
\hline Closed-ended & $\begin{array}{c}\text { Responses to extemporaneous preparation terms based on } \\
\text { traditional pharmaceutical compounding practices }\end{array}$ \\
\hline - Demographics & - The reasons for the most and last preferred learning styles \\
- $\quad$ Background regarding mathematics grades, most recent PCs grades, & \\
- $\quad$ Previously covered sub-topics, & \\
pharmacist, & \\
- Self confidence in solving calculations, \\
- The understanding of the expected GPhC pass mark and familiarity of the \\
type of questions set by the GPhC \\
- Regularly relied on resources
\end{tabular}

A pilot study was conducted $(\mathrm{n}=10)$ using students from year four of the MPharm course. From the study results two main alterations were made in light of the responses. A "Prefer not to say" option was added to questions relating to previous GCSE or A-level mathematics grades as half the students in the pilot refused to answer these questions and also decided not to circle the "Not applicable" option concerning the grade they had obtained in mathematics. Another change was the addition of directions to sets of questions, as it was noticed that students were selecting two or more options where only one was required. Thus, these specific directions restricted students from selecting a number of options and also clarified questions further.

Participants were given a questionnaire containing 22 questions and an information sheet, explaining the reasons to why they have been selected. The questionnaire was handed out before a compulsory Individual Readiness Assurance Test (iRAT) session, maximising attendance. No unique identifiers were included in the questionnaire and participants were verbally informed that all responses would be anonymous and confidential. They were also informed that there was no obligation to take part in the study. The method was applied to both year groups and all returned questions were recorded and accounted for.

The qualitative data was analysed thematically. The thematic analysis combined similar statements the quantitative data was analysed using tables and graphical charts, where trends in results were simply observed between the year groups. Student responses which were submitted incomplete or completely blank were not included in the final study population.

\section{RESULTS}

From a total of 168 students, 148 students took part in the study, equating to a response rate of $88 \%$ (table 2 ).

Table 2: Response rate of the study for second and third years

\begin{tabular}{|c|c|c|c|}
\hline Category & Year 2 & Year 3 & Total \\
\hline Number of students eligible & 90 & 78 & 168 \\
\hline Number of participants & 79 & 69 & 148 \\
\hline Drop outs & 0 & 0 & 0 \\
\hline Response rate (rounded to the nearest whole number) & $88 \%$ & $88 \%$ & $88 \%$ \\
\hline
\end{tabular}


The results gathered from questions 1-5 are presented in table 3 . Of the participants, $93 \%$ had completed GSCE mathematics, with $1 \%$ opting to not state their grades and 5\%reporting taking an equivalent qualification. In addition, 43\%of students also completed A-level mathematics, with $4 \%$ opting not to state their grade.

Table 3: Participants' backgrounds before enrolling on the course

\begin{tabular}{|c|c|c|c|c|}
\hline Category & Available responses & $\begin{array}{l}\text { Number of year } 2 \\
\text { students }\end{array}$ & $\begin{array}{l}\text { Number of year } 3 \\
\text { students }\end{array}$ & $\begin{array}{l}\text { Total Number of } \\
\text { students }\end{array}$ \\
\hline \multirow[t]{2}{*}{ Gender } & Male & 39 & 41 & 80 \\
\hline & Female & 40 & 28 & 68 \\
\hline \multirow[t]{6}{*}{ GCSE mathematics grade } & $A^{*}$ & 4 & 13 & 17 \\
\hline & A & 26 & 28 & 54 \\
\hline & $\mathrm{B}$ & 30 & 20 & 50 \\
\hline & $\mathrm{C}$ & 13 & 4 & 17 \\
\hline & Prefer not to say & 1 & 1 & 2 \\
\hline & Not applicable & 5 & 3 & 8 \\
\hline \multirow[t]{8}{*}{ A-level mathematics grade } & $A^{*}$ & 2 & 1 & 3 \\
\hline & $\mathrm{A}$ & 1 & 10 & 11 \\
\hline & $\mathrm{B}$ & 7 & 16 & 23 \\
\hline & $\mathrm{C}$ & 9 & 9 & 18 \\
\hline & $\mathrm{D}$ & 4 & 4 & 8 \\
\hline & Below D & 1 & 0 & 1 \\
\hline & Prefer not to say & 3 & 3 & 6 \\
\hline & Not applicable & 52 & 26 & 78 \\
\hline \multirow{10}{*}{$\begin{array}{l}\text { Pharmaceutical calculation sub-topics covered } \\
\text { before learning about them at University }\end{array}$} & Doses calculation & 29 & 27 & 56 \\
\hline & Dilutions & 23 & 40 & 63 \\
\hline & $\begin{array}{l}\text { Displacement volumes } \\
\text { and values }\end{array}$ & 22 & 34 & 56 \\
\hline & Concentrations & 31 & 39 & 70 \\
\hline & Quantities to supply & 18 & 28 & 46 \\
\hline & Molecular weights & 59 & 58 & 117 \\
\hline & Using provided formulae & 48 & 43 & 91 \\
\hline & Infusion rates & 6 & 19 & 25 \\
\hline & Pharmacokinetics & 10 & 13 & 23 \\
\hline & Health economics & 4 & 6 & 10 \\
\hline
\end{tabular}

The results obtained from questions 6-9are presented in table 4; $86 \%$ of participants felt PCs were vital for the MPharm degree and $85 \%$ agreed on the importance of calculations to their future careers. Also, $32 \%$ of students felt they either needed more support or lacked confidence in solving PCs compared to the $68 \%$ who generally felt confident or very confident. However, within both year groups, $10 \%$ of students scored under $70 \%$ in their final examination compared to $87 \%$ achieving a comfortable pass rate, possibly due to $52 \%$ of students regularly relying on additional text books, $10 \%$ on private tuition, $43 \%$ on videos and $4 \%$ on workbooks.

Table 4: Responses to questions 6-9

\begin{tabular}{|c|c|c|c|c|}
\hline category & Available responses & $\begin{array}{l}\text { Number of year } 2 \\
\text { students }\end{array}$ & $\begin{array}{l}\text { Number of year } 3 \\
\text { students }\end{array}$ & $\begin{array}{l}\text { Total number of } \\
\text { students }\end{array}$ \\
\hline Importance of pharmaceutical calculations to & Not important at all & 0 & 2 & 2 \\
\hline \multirow[t]{4}{*}{ MPharm degree } & Somewhat important & 0 & 1 & 1 \\
\hline & Important & 8 & 3 & 11 \\
\hline & Very important & 16 & 8 & 24 \\
\hline & Absolutely essential & 55 & 38 & 93 \\
\hline \multirow{5}{*}{$\begin{array}{l}\text { Importance of pharmaceutical calculations to } \\
\text { future job as a pharmacist }\end{array}$} & Not important at all & 0 & 0 & 0 \\
\hline & Somewhat important & 4 & 0 & 4 \\
\hline & Important & 8 & 7 & 15 \\
\hline & Very important & 14 & 11 & 25 \\
\hline & Absolutely essential & 53 & 33 & 86 \\
\hline \multirow{4}{*}{$\begin{array}{l}\text { Self-confidence at solving pharmaceutical } \\
\text { calculation questions }\end{array}$} & Very confident & 10 & 16 & 26 \\
\hline & Confident & 43 & 31 & 74 \\
\hline & Need more support & 24 & 21 & 45 \\
\hline & Not confident & 2 & 1 & 3 \\
\hline \multirow{5}{*}{$\begin{array}{l}\text { End-of year pharmaceutical calculations exam } \\
\text { score }\end{array}$} & Can't remember & 0 & 1 & 1 \\
\hline & Less than $39 \%$ & 1 & 1 & 2 \\
\hline & $39-69 \%$ & 7 & 5 & 12 \\
\hline & $70 \%+$ & 69 & 60 & 129 \\
\hline & Prefer not to say & 2 & 2 & 4 \\
\hline \multirow[t]{4}{*}{ Additional resources regularly relied on: } & Text books & 36 & 41 & 77 \\
\hline & Private tuition & 7 & 8 & 15 \\
\hline & YouTube clips & 33 & 30 & 63 \\
\hline & Other (Workbooks) & 6 & 0 & 6 \\
\hline
\end{tabular}


Table 5 reports participants' perception of the pre-registration exam. Generally within both year groups, more than $50 \%$ of participants were aware of all the different types of questions set by the GPhC, except for questions based around estimations of kidney functions and health economics. Also, $65 \%$ of students estimated the $\mathrm{GPhC}$ examination pass rate at $70 \%$ and over, where $6 \%$ estimated a pass mark of $50 \%$ or under.

Table 5: Responses to questions 10 and 11

\begin{tabular}{|c|c|c|c|c|}
\hline Category & Available responses & $\begin{array}{l}\text { Number of year } 2 \\
\text { students }\end{array}$ & $\begin{array}{l}\text { Number of year } 3 \\
\text { students }\end{array}$ & $\begin{array}{l}\text { Total number of } \\
\text { students }\end{array}$ \\
\hline \multirow{12}{*}{$\begin{array}{l}\text { Familiarity of the different type of } \\
\text { questions set by the GPhC }\end{array}$} & Doses and dose regimens & 54 & 54 & 108 \\
\hline & Dosage and unit conversion & 63 & 53 & 116 \\
\hline & Estimations of kidney functions & 9 & 8 & 17 \\
\hline & Displacement volumes and values & 43 & 44 & 87 \\
\hline & Concentrations & 68 & 54 & 122 \\
\hline & $\begin{array}{l}\text { Dilutions, including concentrated } \\
\text { waters }\end{array}$ & 48 & 45 & 93 \\
\hline & Molecular weight & 54 & 47 & 101 \\
\hline & Using provided formulae & 41 & 44 & 85 \\
\hline & Infusion rates & 13 & 33 & 46 \\
\hline & pharmacokinetics & 19 & 14 & 35 \\
\hline & Health economics & 3 & 1 & 4 \\
\hline & Quantity to supply & 39 & 37 & 76 \\
\hline \multirow{4}{*}{$\begin{array}{l}\text { Understanding the pass } \% \text { mark for } \\
\text { the GPhC PC exam }\end{array}$} & $40 \%$ & 3 & 1 & 4 \\
\hline & $50 \%$ & 3 & 2 & 5 \\
\hline & $70 \%$ & 45 & 51 & 96 \\
\hline & $90-100 \%$ & 28 & 15 & 43 \\
\hline
\end{tabular}

Presented in table6 are the categorised responses to question 12-19 which were collated and analysed using a thematic approach. Questions 12-19 were included at the request of teaching staff who wished to establish whether students are familiar with some of the key components of CP involving EPs. One hundred participants chose not to answer questions 12-19 leaving only 48 participants for this specific section.

Tables 7 and 8 are thematic analysis students' responses about the reasons of the most and least preferred learning styles.

Table 6: Responses to questions 12-19

\begin{tabular}{|c|c|c|c|c|}
\hline Questions & Themes derived & $\begin{array}{l}\text { Responses } \\
\text { (\%) year } 2 \\
\text { students }\end{array}$ & $\begin{array}{l}\text { Responses } \\
\text { (\%) year } 3 \\
\text { students }\end{array}$ & $\begin{array}{l}\text { Responses }(\%) \\
\text { all participants }\end{array}$ \\
\hline \multirow{2}{*}{$\begin{array}{l}\text { What therapeutic indication is potassium permanganate } \\
\text { solution used for? }\end{array}$} & Answer incorrect & 83 & 17 & 13 \\
\hline & $\begin{array}{l}\text { Unsure, don't know or } \\
\text { made no comment }\end{array}$ & 33 & 67 & 87 \\
\hline \multirow[t]{3}{*}{ Why is potassium permanganate diluted before use? } & Answer partly correct & 8 & 92 & 27 \\
\hline & Answer incorrect & 78 & 22 & 19 \\
\hline & $\begin{array}{l}\text { Unsure, don't know or } \\
\text { made no comment }\end{array}$ & 42 & 58 & 54 \\
\hline \multirow{3}{*}{$\begin{array}{l}\text { What adverse reactions can potassium permanganate } \\
\text { solution cause? }\end{array}$} & Answer partly correct & 0 & 100 & 8 \\
\hline & Answer incorrect & 20 & 80 & 10 \\
\hline & $\begin{array}{l}\text { Unsure, don't know or } \\
\text { made no comment }\end{array}$ & 46 & 54 & 81 \\
\hline \multirow[t]{3}{*}{ What is chloroform water used for? } & Answer partly correct & 0 & 100 & 6 \\
\hline & Answer incorrect & 0 & 100 & 2 \\
\hline & $\begin{array}{l}\text { Unsure, don't know or } \\
\text { made no comment }\end{array}$ & 43 & 57 & 92 \\
\hline \multirow{2}{*}{$\begin{array}{l}\text { What percentage strength is single strength chloroform } \\
\text { water? }\end{array}$} & Answer incorrect & 33 & 67 & 12.5 \\
\hline & $\begin{array}{l}\text { Unsure, don't know or } \\
\text { made no comment }\end{array}$ & 40 & 60 & 87.5 \\
\hline What is the standard \% v/v strength for: concentrated & Answer incorrect & 40 & 60 & 10 \\
\hline $\begin{array}{l}\text { chloroform water, concentrated peppermint water, } \\
\text { concentrated witch hazel }\end{array}$ & $\begin{array}{l}\text { Unsure, don't know or } \\
\text { made no comment }\end{array}$ & 40 & 60 & 80 \\
\hline Betamethasone ointment standard strength is $0.1 \% \mathrm{w} / \mathrm{v}$. & Answer partly correct & 38 & 62 & 17 \\
\hline \multirow[t]{2}{*}{ Why might you wish to dilute this with white soft paraffin? } & Answer incorrect & 44 & 56 & 19 \\
\hline & $\begin{array}{l}\text { Unsure, don't know or } \\
\text { made no comment }\end{array}$ & 39 & 61 & 65 \\
\hline $\begin{array}{l}\text { Two antibiotic bottles both contain } 1 \mathrm{~g} \text { of dry powder for } \\
\text { reconstitution to } 100 \mathrm{ml} \text {. To reconstitute these to } 100 \mathrm{ml} \text {, }\end{array}$ & Answer partly correct & 86 & 14 & 29 \\
\hline you add $75 \mathrm{ml}$ of water to one bottle and $85 \mathrm{ml}$ to the other & Answer incorrect & 57 & 43 & 15 \\
\hline $\begin{array}{l}\text { bottle. Assuming both of these are correct, can you explain } \\
\text { why these two volumes differ? }\end{array}$ & $\begin{array}{l}\text { Unsure, don't know or } \\
\text { made no comment }\end{array}$ & 33 & 67 & 56 \\
\hline
\end{tabular}


Table 7: Thematic analysis on second year students' responses

\begin{tabular}{|c|c|c|c|c|c|}
\hline Learning styles & Whole-class lectures & $\begin{array}{l}\text { Workbooks } \\
\text { only }\end{array}$ & Formative assessments & $\begin{array}{l}\text { Workshops with } \\
\text { tutor and workbook }\end{array}$ & Videos \\
\hline $\begin{array}{l}\text { Responses for most } \\
\text { preferred }\end{array}$ & $\begin{array}{l}\text { Visual learner (7) } \\
\text { Detailed explanations (2) }\end{array}$ & $\begin{array}{l}\text { Independent } \\
\text { learning (7) }\end{array}$ & $\begin{array}{l}\text { Practice questions (3) } \\
\text { Similar to the real exam } \\
(4) \\
\text { Recognise areas of } \\
\text { weakness (7) }\end{array}$ & $\begin{array}{l}\text { Apply knowledge (6) } \\
\text { Ask for help (18) }\end{array}$ & $\begin{array}{l}\text { Can re-watch } \\
\text { again (4) } \\
\text { Visual/audio } \\
\text { learner (2) }\end{array}$ \\
\hline $\begin{array}{l}\text { Responses for least } \\
\text { preferred }\end{array}$ & $\begin{array}{l}\text { No interaction (5) } \\
\text { Independent leaner ( } 3 \text { ) } \\
\text { learn at a different pace } \\
\text { (3) } \\
\text { Lack of concentration (4) }\end{array}$ & $\begin{array}{l}\text { Can't ask } \\
\text { questions (10) } \\
\text { Hard to cover } \\
\text { new concept } \\
\text { alone (3) }\end{array}$ & Pressure (9) & $\begin{array}{l}\text { Independent learner } \\
(3) \\
\text { Lack of concentration } \\
(4)\end{array}$ & $\begin{array}{l}\text { Lack of detail (4) } \\
\text { can't ask } \\
\text { questions (10) } \\
\text { A single method } \\
\text { shown (2) }\end{array}$ \\
\hline $\begin{array}{l}\text { Participants who did not } \\
\text { attempt the question }\end{array}$ & 19 & & & & \\
\hline
\end{tabular}

*brackets indicate the number of students whose responses fit into the theme

Table 8: Thematic analysis on third year students' responses

\begin{tabular}{|c|c|c|c|c|c|}
\hline Learning styles & $\begin{array}{l}\text { Whole-class } \\
\text { Lectures }\end{array}$ & $\begin{array}{l}\text { Workbooks } \\
\text { only }\end{array}$ & $\begin{array}{l}\text { Formative } \\
\text { assessments }\end{array}$ & $\begin{array}{l}\text { Workshops with tutor } \\
\text { and workbook }\end{array}$ & Videos \\
\hline $\begin{array}{l}\text { Responses for most } \\
\text { preferred }\end{array}$ & $\begin{array}{l}\text { Visual leaner (4) } \\
\text { Interaction, can ask } \\
\text { questions (4) }\end{array}$ & $\begin{array}{l}\text { Independent } \\
\text { learning (6) } \\
\text { Good revision } \\
\text { tool (4) }\end{array}$ & $\begin{array}{l}\text { Practice exam style } \\
\text { questions (5) } \\
\text { Identify areas of } \\
\text { weakness (3) }\end{array}$ & $\begin{array}{l}\text { Apply knowledge (10) } \\
\text { Verbal explanations (8) } \\
\text { Number of methods shown } \\
\text { and interaction (11) }\end{array}$ & $\begin{array}{l}\text { visual learner (3) } \\
\text { practice questions (3) }\end{array}$ \\
\hline $\begin{array}{l}\text { Responses for least } \\
\text { preferred }\end{array}$ & $\begin{array}{l}\text { difficult to keep up } \\
\text { (8) } \\
\text { no interaction (6) } \\
\text { Loss of attention (4) }\end{array}$ & $\begin{array}{l}\text { Can't ask } \\
\text { questions (12) } \\
\text { Hard for new } \\
\text { concepts (4) }\end{array}$ & $\begin{array}{l}\text { Not good as a } \\
\text { learning style (2) }\end{array}$ & $\begin{array}{l}\text { Independent learner (2) } \\
\text { Loss of concentration (2) }\end{array}$ & $\begin{array}{l}\text { No interaction (17) } \\
\text { No as straight forward } \\
\text { when applying } \\
\text { knowledge (4) }\end{array}$ \\
\hline $\begin{array}{l}\text { Participants who did } \\
\text { not attempt the } \\
\text { question }\end{array}$ & 8 & & & & \\
\hline
\end{tabular}

*brackets indicate the number of students whose responses fit into the theme, Question 20 represented in fig. 1-5 ranked the learning styles in graphical charts. The responses from both second and third years were merged and ranked. Work shop was selected as first option, followed by formative assessments and workbooks and lectures and videos came last.

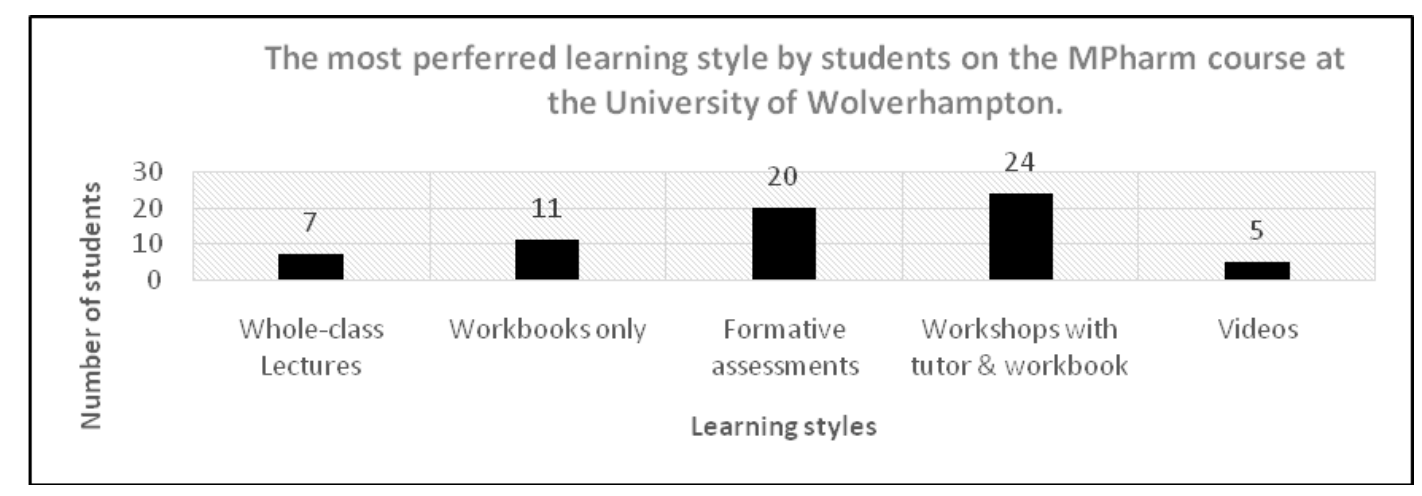

Fig. 1: The number of students who rankedthe available learning styles as their most preferred

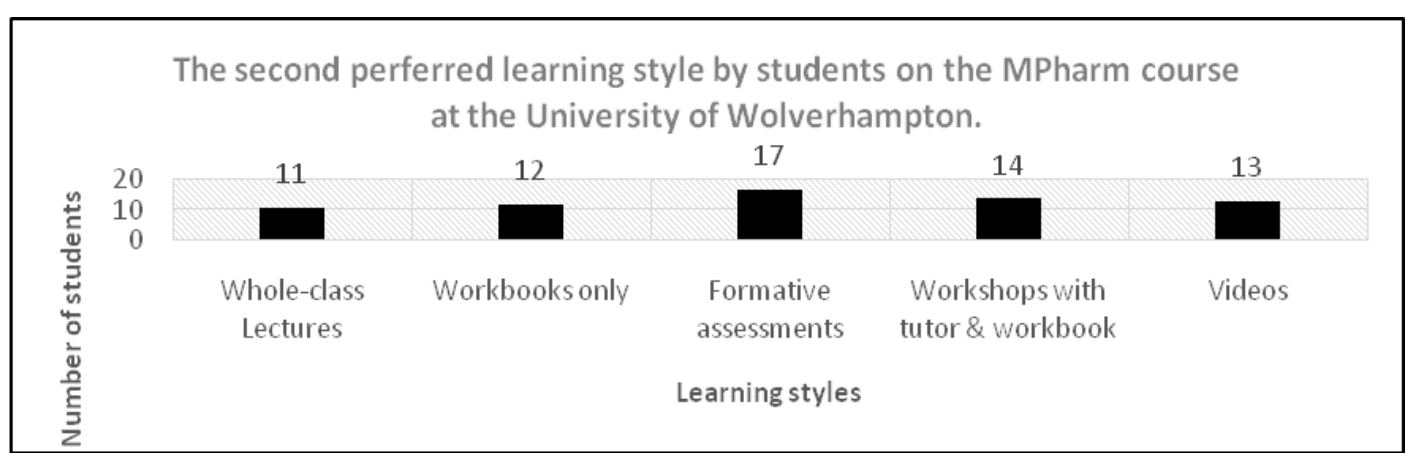

Fig. 2: The number of students who ranked the available learning styles as their second preferred 


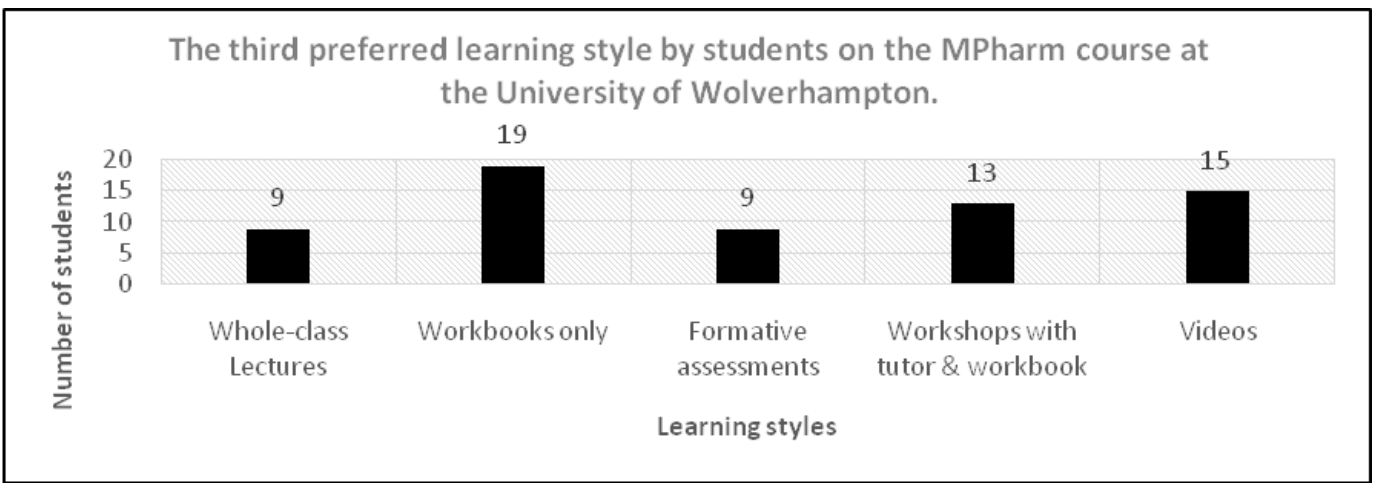

Fig. 3: The number of students who ranked the available learning styles as their third preferred

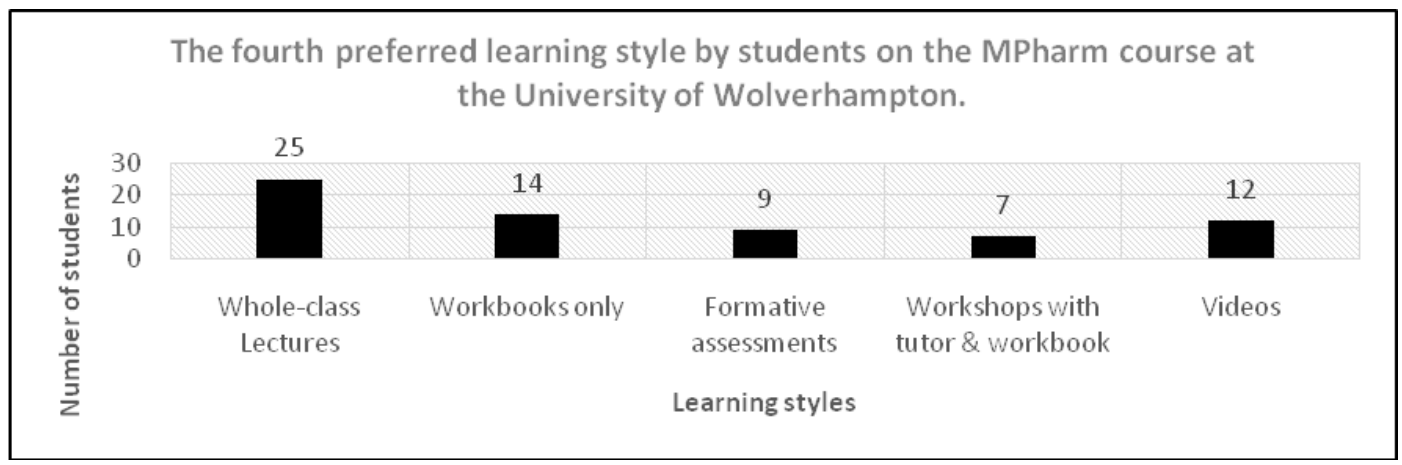

Fig. 4: The number of students who ranked the available learning styles as their fourth preferred

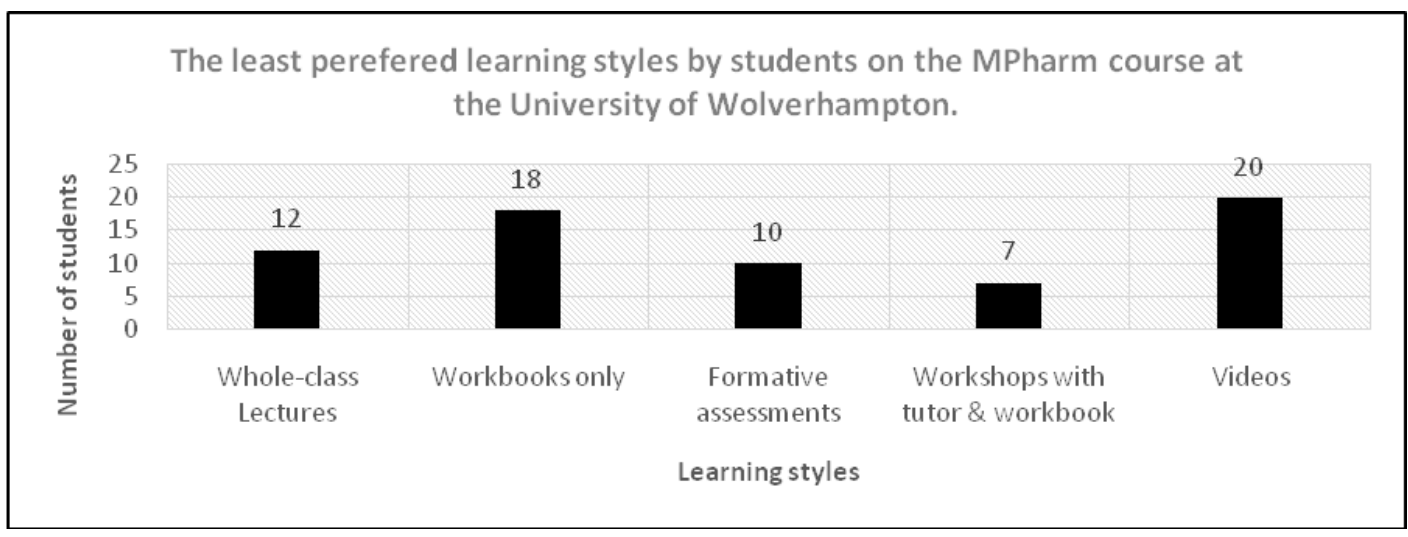

Fig. 5: The number of students who ranked the available learning styles as their least preferred

Table 6: Thematic analysis on the overall responses for question 21-22

\begin{tabular}{|c|c|c|c|c|c|}
\hline $\begin{array}{l}\text { Learning } \\
\text { styles }\end{array}$ & Whole-class lectures & Workbooks only & $\begin{array}{l}\text { Formative } \\
\text { assessments }\end{array}$ & $\begin{array}{l}\text { Workshops with } \\
\text { tutor and workbook }\end{array}$ & Videos \\
\hline Positive & $\begin{array}{l}\text { Visual learner (11) } \\
\text { Detailed explanations } \\
\text { (2) } \\
\text { Interaction, can ask } \\
\text { questions (4) }\end{array}$ & $\begin{array}{l}\text { Independent learning } \\
(13) \\
\text { Good revision tool } \\
\text { (4) }\end{array}$ & $\begin{array}{l}\text { Practice questions (8) } \\
\text { Similar to the real } \\
\text { exam (4) } \\
\text { Recognise areas of } \\
\text { weakness (10) }\end{array}$ & $\begin{array}{l}\text { Apply knowledge (16) } \\
\text { Ask for help (18) } \\
\text { Verbal explanations (8) } \\
\text { Number of methods } \\
\text { shown and } \\
\text { interaction (11) }\end{array}$ & $\begin{array}{l}\text { Can re-watch again (4) } \\
\text { Visual/audio learner (5) } \\
\text { practice questions (3) }\end{array}$ \\
\hline Negative & $\begin{array}{l}\text { No interaction (11) } \\
\text { Independent leaner ( } 3) \\
\text { Lack of concentration } \\
\text { (8) } \\
\text { difficult to keep up (11) } \\
27\end{array}$ & $\begin{array}{l}\text { Can't ask questions } \\
(22) \\
\text { Hard to cover new } \\
\text { concept alone (7) }\end{array}$ & $\begin{array}{l}\text { Pressure (9) } \\
\text { Not good as a learning } \\
\text { style (2) }\end{array}$ & $\begin{array}{l}\text { Independent learner } \\
(5) \\
\text { Loss of concentration } \\
(6)\end{array}$ & $\begin{array}{l}\text { Lack of detail (4) } \\
\text { Can't ask questions (10) } \\
\text { A single method shown (2) } \\
\text { No interaction (17) } \\
\text { No knowledge application (4) }\end{array}$ \\
\hline
\end{tabular}

*Brackets indicate the number of students whose responses fit into the theme 
Finally question 21-22, presented in table 7 were analysed using the thematic analytic technique. Only 121 students answered the questions. During the analysis, a range of similar themes were found and all answers to questions were read thoroughly to identify repetition. The responses were initially assessed in terms of for and against each type of learning style; they were then counted and recorded in terms of occurrence of themes.

\section{DISCUSSION}

The results from this study are broadly similar to other published studies. An advantage of this study is that because our students are exposed to a variety of styles of delivery, they are able to make informed judgements about which methods they prefer, and what they believe enhances their academic performance and clearly these are not necessarily the same thing.

From our study, 67 participants; (36\%) stated they most preferred workshops with a tutor and a workbook as their learning style. From 121 students, 53 provided positive responses as to why they believed these workshops were more beneficial than the other listed options. The themes that emerged highlighted how "verbal explanations" was perceived to facilitate better understanding of the content and improved performance. Of the students who ranked workshops as their most preferred learning style, $96 \%$ of students achieved grades of $70 \%$ or over in their final PCs exam. Similarly, Ofsted and Brunner ${ }^{9}$ expressed how the "interaction" of staff and individuals at workshops was able to increase marks by around $20 \%$. They suggested this may be due to having the opportunity to "ask for help" at the first instances or being able to "apply knowledge" they have gained from the demonstrations immediately and receive feedback. Within active workshops, tutors are perceived to demonstrating more than one learning method when compared to didactic lectures. Batchelor ${ }^{5}$ stated this as a reason why more than $50 \%$ of students learn when a variety of methods were used and students were able to select a preferred method for future use, having a positive impact on improving retention and performance $[10,11]$. Conversely 11 students did not consider workshops to be most beneficial; they perceived the long duration caused concentration fatigue and loss of focus with 5 students preferring to work independently rather than in a workshop.

Overall, $25 \%$ of participants favoured formative assessments as their second preferred learning style. Twenty two students left positive responses highlighting the impact of this learning style on performance. As seen by exam results, $94 \%$ of students (who ranked formative assessments in second place) received $70 \%$ or over and only $6 \%$ received between $39-69 \%$.

A common theme identified how this particular learning style "recognises areas of weakness" due to individualised feedback. Gums [22] claimed this leads to higher test scores. More than half of the students who left a positive comment, stated formative assessments were "similar to real exams" and how these questions were best used for "practice" purposes. Both Nutan [23] and Lacroix [24] and Enz and Frosch [21] agreed; students who participate in regular formative assessments, stress less so this learning style relieves students' anxiety without affecting their retention or performance $[3,20]$. However 9 students reported feeling "pressurised" by regular assessments and 2 students suggested formative assessments are "not good as a learning style" since no actual learning takes place, suggesting they are better as an indicator of what an individual knows or understands.

All participants ranked workbooks in third position. Seventeen students made positive comments compared to 29 who identified disadvantages of using workbooks on their own. All the students who commented on workbooks achieved grades of $70 \%$ and over. Less than half of these identified as being "independent learners" and thus preferred all the content within workbooks. Also Branch and Rodgers [14] expressed how students prefer this type of style due to them being able to work at their own pace and within their own comfort and time, thus getting a better grasp at the sub-topics. 4 students particularly liked using the workbooks as a "revision tool". On the other hand, more disadvantages were stated by students, in fact 22 students disapproved of the learning style due to being "unable to ask questions" and the lack of interaction amongst students and tutors. In agreement, Van [15] claimed being unable to address issues face to face can affect performance. Also students felt these booklets covering sub-topics were "hard to cover as a new concept alone" and therefore required a tutor to display and explain methods step by step which they can later apply to questions in the future.

There was 37\% displays whole-class lecturers as the fourth ranked learning style amongst the selection. 17 positive comments where compared against 33 negative comments about this particular learning style. $96 \%$ of these students achieved grades of $70 \%$ over, while $4 \%$ received grades of less than $39 \%$ in their final PCs examination. The most common theme derived by students was being "visual learners" and favouring the addition of "interaction" with tutors. The findings suggest like Fike [17], students felt the "interaction" allowed them to "ask questions" at any stage of the "detailed" demonstration and explanations, thus further enhancing students understanding, retention and academic performance. However 11 student stated how they were "unable to keep up" with whole-class lectures due to the fast pace. Also the full on lectures with large groups of individuals led students to "lacking in concentration" and "interaction", in which Preszler and Hoopes [10] believes smaller classes will increase interactive engagement, cooperation and are more preferable by students. A minority of students claimed to be "independent learners" and therefore prefer to work on their own, which is supported by Fike [17] who expresses how no significant differences have been portrayed in grades from students who attend lectures to those who wish not to.

Amongst 67 participants, $30 \%$ least preferred videos compared to the other options. 12 students left positive comments while 37 individuals mentioned negative aspects about the learning style. $95 \%$ of students who generally commented on videos achieved grades of $70 \%$ and over, while $5 \%$ achieved grades between $39-$ $69 \%$. Most students stated themselves as being "visual or audio learners" whereas others generally felt using videos had a benefit of being "re-watched" again to either relook at difficult concepts right from a beginner's stage or replaying videos for revision purposes. This finding is further supported by Powers [18] and Karyn [16], who express how revisiting concepts multiples of times aid understanding and enhances learning and performance. Also students favoured the "practice questions" built within the videos as it gave them the opportunity to attempt methods, in agreement with Karyn [16] this aspect is known to improve exam grades. On the other hand students claimed the videos were "not interactive" and "not as straight forward when applying knowledge" thus disadvantaging its benefits with a "single method" being demonstrated which "lacked in detail". Van [15] also supported a theme derived on how videos eliminate the chances of "asking questions" which is one of the reasons why students prefer face to face learning styles compared to those over a screen.

Finally although no assumptions should be made when analysing the results, the fact that 100 out of $148(68 \%)$ students chose not to answer questions 12-19 implies that they were either unable to answer them or were not comfortable to do so. A range of $54-92 \%$ of participants took the opportunity to state either that they were "unsure" or "didn't know" the answers to the questions (table 5). Regardless of the year group, no single student was able to completely state the correct answers. The results reflect that the UoW need to consider addressing the issue of students being unaware or lacking understanding of the terms used within PC questions. They would also need to consider using a learning style which is most favoured by students and believed to be more beneficial in terms of enhancing performance.

One of the main limitations, was during the analysis of responses, a flaw was noticed in question 20 , which asked students to rank the currently used learning styles for PCs in terms of preference and benefit. Less than half of participants ranked learning styles compared to the majority which used the numbers $1-5$ as a Likert scale. This could have possibly been due to the layout of the question, where each learning style had an option to circle a number of 1-5 or may have been due to students rushing the questionnaire and therefore not reading the directions in bold which asked them to 
rank the learning styles. Another aspect which may have cause student to use the numbers as a Likert scale was the fact that the questionnaire was handed out just before an iRAT exam, and thus leading students to rush the questionnaire to start their iRAT which is known to count partly for a core module grade. For future projects, the administration of the questionnaire would not be handed out before a timetabled exam and numbers from 1-5 would not be displayed in a table format for circling, instead students would be asked to physically rank the learning styles by writing numbers $1-5$ by each option and only using each number once.

\section{LIMITATIONS}

Participants had different educational levels background e. g. B-level, A-level and GSEC, which could have possibly led to students preferring a learning style which they are familiar with. For future studies, inclusion and exclusion criteria would be applied to participants. Specifically for this study, students who regularly rely on additional sources (such as text books/private tutors) would need to be excluded as they would be achieving help outside the scope of the learning styles used to teach them a sub-topics, which would in fact effect their perception of the learning style. All participants would need to have an equal mathematics and PCs background with no additional support to obtain a fair representation on the learning styles that influence performance.

\section{CONCLUSION}

To conclude, it can be said that a significant number of second and third year students in the study sample ranked the currently used learning style in the following order: workshops, formative assessments, workbooks alone, whole-class lectures and videos, due to preferences which benefits their academic performance. The specific findings suggest that the views of students were similar to the authors from recent literature.

It was also identified that student slack an understanding of extemporaneous preparation terms and thus require more support to appreciate the need to learn compounding calculations. The university could potentially use a learning style, such as practicums, to teach this aspect of calculations.

\section{ACKNOWLEDGMENT}

The School of Pharmacy; University of Wolverhampton, UK.

\section{AUTHORS CONTRIBUTIONS}

All the author have contributed equally

\section{CONFLICTS OF INTERESTS}

The authors declare no conflict of interest

\section{REFERENCES}

1. Rauniar GP, Das BP, Bhattacharya SK. Drug dose calculation need to be drilled. Nepal Med College J 2006;8:143-4.

2. Fleming S, Brady A, Malone A. An evaluation of the drug calculation skills of registered nurses. Nurse Educ Practice 2014;14:55-61.

3. Mehvar R. The importance of active learning and practice on the students' mastery of pharmacokinetic calculations for the intermittent intravenous infusion dosing of antibiotics. BMC Med Educ 2012;12:116.

4. General Pharmaceutical Council (GPhC). About the papers: Find out about changes to 2016 registration assessment. Available from: https://www.pharmacyregulation.org/about-papers. [Last accessed on 02 Oct 2016]

5. Batchelor H. A constructivist method for teaching concentration calculations to pharmacy students. Pharm Educ 2007;7:69-76.

6. University of Wolverhampton. M Pharm (Hons) Master of pharmacy (M Pharm). Available from: http:// courses.wlv.ac.uk/course.asp?code=PY003Q01UVU [Last accessed on 02 Oct 2016]

7. Williams B, Brown T, Etherington J. Learning style preferences of undergraduate pharmacy students. Curr Pharm Teach Learning 2013;5:110-9.
8. Giuliano CA, Moser LR, Poremba V, Jones J, Martin ET, Slaughter RL. Use of a unified learning style model in pharmacy curricula. Curr Pharm Teach Learning 2014;6:41-57.

9. Ofstad W, Brunner LJ. Team-based learning in pharmacy education. Am J Pharm Educ 2013;77:70.

10. Preszler RW, Hoopes LLM. Replacing lecture with peer-led workshops improves student learning. CBE Life Sci Educ 2009;8:182-92.

11. Sawbridge JL, Qureshi HK, Boyd MJ, Brown AM. Revision workshops in elementary mathematics enhance student performance in routine laboratory calculations. Adv Physiol Educ 2014;38:239-45.

12. Wright K. Can effective teaching and learning strategies help student nurses to retain drug calculation skills? Nurse Educ Today 2008;28:856-64.

13. Bergen P, McDowell J, Elliott RA, Roller L, Kong D. Development of an online pharmaceutical calculations learning module learning module. Pharm Educ 2011;11:21-5.

14. Branch C, Rodgers R. Case study: pharmaceutical calculations without tears. Medway School Pharm 2013;1:1-4.

15. Van LA, Baldewijns K, Verhaeghe R, Robays H, Buyle F, Colman $\mathrm{R}$, et al. The effectiveness of an e-learning course on medication calculation in nursing students: a clustered quasi-experimental study. J Adv Nurs 2016;72:2054-64.

16. Karyn I, Cotta KI, Shah S, Almgren MM, Macias Moriarity LZ, Mody V. Effectiveness of flipped classroom instructional model in teaching pharmaceutical calculations. Curr Pharm Teach Learning 2016;8:646-53.

17. Fike DS, McCall KL, Raehl CL, Smith QR, Lockman PR. Achieving equivalent academic performance between campuses using a distributed education model. Am J Pharm Educ 2009;73:88.

18. Powers MF, Bright DR, Buqai PS. A brief report on the use of paper-based computing to supplement a pharmaceutical calculations course. Curr Pharm Teach Learning 2010;2:144-8.

19. Glaister K. Exploring the impact of instructional approaches on the learning and transfer of medication dosage calculation competency. Contemporary Nurse 2005;20:3-13.

20. Hegener MA, Buring SM, Papas E. Impact of a required pharmaceutical calculations course on mathematics ability and knowledge retention. Am J Pharm Educ 2013;77:124.

21. Enz S, Frosch DR. Effect of collaborative vs. noncollaborative quizzes on examination scores in a pharmaceutical calculations course. Am J Pharm Educ 2015;79:66.

22. Gums TH, Kleppinger EL, Urick BY. Outcomes of individualized formative assessments in a pharmacy skills laboratory. Am J Pharm Educ 2014;78:166.

23. Nutan MTH, Demps EL. Online assessments in pharmaceutical calculations for enhancing feedback and practice opportunities. Curr Pharm Teach Learning 2014;6:807-14.

24. Lacroix M, McCall III KL, Fike DS. The keller personalized system of instruction in a pharmacy calculations course: a randomized trial. Curr Pharm Teach Learning 2014;6:348-52.

25. Gleason BL, Peeters MJ, Resman Targoff BH, Karr S, McBane S, Kelley $\mathrm{K}$, et al. An active-learning strategies primer for achieving ability-based educational outcomes. Am J Pharm Educ 2011;75:186.

26. Brown MC, Hanggi A. Pharmaceutical calculations instruction and assessment in us colleges and schools of pharmacy. Am J Pharm Educ 2007;71:87.

27. General Pharmaceutical Council (GPhC). Results of September 2016 registration assessment. Available from: http://www.pharmacyregulation.org/news/results-september2016-registration-assessment. [Last accessed on $10 \mathrm{Feb}$ 2017]

28. Pope C, Nicholas M, Popay J. Synthesizing qualitative and quantitative health evidence. Berkshire: Open University Press; 2007.

29. Fereday J, Muir-cochrane E. Demonstrating rigor using thematic analysis: a hybrid approach of inductive and deductive coding and theme development. Int J Qualitative Methods 2006;5:1-11.

30. Leininger MM. Ethnography and ethnonursing: models and modes of qualitative data analysis. Qualitative Res Methods Nursing 1985;3:33-72.

31. Meyler L, Ramtoola Z, Barlow J. Evaluation of the ability of pharmacy and medicine students to calculate drug dosage. Pharm Educ 2011;11:186-9. 
32. Wright K. Do calculation errors by nurses cause medication errors in clinical practice? A literature review. Nurse Educ Today 2010;30:85-97.

33. Smith F. Research methods in pharmacy practice. London: Pharmaceutical Press; 2002.

34. Wright KB. Researching internet-based populations: advantages and disadvantages of online survey research, online questionnaire authoring software packages, and web survey services. J Computer Mediated Communication 2005;10:11.

35. Alshenqeeti $\mathrm{H}$. Interviewing as a data collection method: a critical review. English Linguistics Res 2014;3:39-45.

36. Llieva J, Baron S, Healey NM. Online surveys in marketing research: pros and cons. Int J Market Res 2002;44:361-7.

37. Andrews D, Nonnecke B, Preece J. Electronic survey methodology: a case study in reaching hard-to-involve internet users. Int J Human Computer Interaction 2003;16:185-210.

38. Bachmann D, Elfrink J. Tracking the progress of e-mail versus snail-mail. Marketing Res 1996;8:31-5.
39. Couper MP. Web-based surveys: a review of issues and approaches. Public Opinion Quarterly 2002;64:464-94.

40. Yun GW, Trumbo CW. Comparative response to a survey executed by post, email, and web form. J Computer Mediated Communication 2002;6:1-2.

41. Sudman S, Greeley A, Pinto L. The effectiveness of selfadministered questionnaires. J Marketing Res 1965;2:293-7.

42. Reja U, Manfreda KL, Hlebec V, Vehovar V. Open-ended vs. close-ended questions in web questionnaires. Dev Appl Statistics 2003;19:1-19.

43. Harzing AW. Rating versus ranking: what is the best way to reduce response and language bias in cross-national research? Int Business Rev 2009;18:1-32.

44. University of Loughborough. Questionnaire Design. Available from: http://www.lboro.ac.uk/services/library/students/learningsuppo rt/topics/questionnairedesign/. [Last accessed on 02 Oct 2016]

45. Boynton PM, Greenhalgh T. Selecting, designing, and developing your questionnaire. Br Med J 2004;328:1312-5. 